\title{
Placental Abruption in the Obstetrics and Gynecology Service of Regional Hospital Center of Ouahigouya: Epidemiological, Clinical Ant and Therapeutic Aspects about 89 Cases Collected from $1^{\text {st }}$ January 2013 to $31^{\text {st }}$ December 2015
}

\author{
Issa Ouédraogo ${ }^{1,2^{*}}$, Yobi Alexis Sawadogo ${ }^{1,3}$, Dantola Paul Kain 1,3, Hyacinthe Zamane ${ }^{1,3}$, \\ Sansan Rodrigue Sib1,2, Sibraogo Kiemtore ${ }^{1,3}$, Adama Ouattara ${ }^{1,3}$, Ali Ouédraogo ${ }^{1,3}$, \\ Justin Payirwendé Yao², Blandine Thieba1,3, Jean Lankoandé1,3
}

\begin{abstract}
${ }^{1}$ Department of Obstetrics and Gynecology, Yalgado Ouedraogo Teaching Hospital in Ouagadougou, Ouagadougou, Burkina Faso ${ }^{2}$ Department of Obstetrics and Gynecology, Teaching Hospital in Ouahigouya, Ouahigouya, Burkina Faso ${ }^{3}$ Unity of Training and Research in Health Sciences (UFR/SDS), University of Ouagadougou, Ouagadougou, Burkina Faso Email: *oued_issa2002@yahoo.fr
\end{abstract}

How to cite this paper: Ouédraogo, I., Sawadogo, Y.A., Kain, D.P., Zamane, H., Sib, S.R., Kiemtore, S., Ouattara, A., Ouédraogo, A., Yao, J.P., Thieba, B. and Lankoandé, J. (2017) Placental Abruption in the Obstetrics and Gynecology Service of Regional Hospital Center of Ouahigouya: Epidemiological, Clinical Ant and Therapeutic Aspects about 89 Cases Collected from $1^{\text {st }}$ January 2013 to $31^{\text {st }}$ December 2015. Open Journal of Obstetrics and Gynecology, 7, 86-94.

http://dx.doi.org/10.4236/ojog.2017.71010

Received: December 14, 2016

Accepted: January 7, 2017

Published: January 10, 2017

Copyright $\odot 2017$ by authors and Scientific Research Publishing Inc. This work is licensed under the Creative Commons Attribution International License (CC BY 4.0).

http://creativecommons.org/licenses/by/4.0/

\section{Abstract}

Objective: To study epidemiological, clinical ant therapeutic aspects of placental abruption in the service of obstetrics and gynecology of regional hospital center of $\mathrm{Ou}$ ahigouya. Methods: We conducted a cross-sectional study scheduled for 3 years, from $1^{\text {st }}$ January 2013 to $31^{\text {st }}$ December 2015. Data were collected from patients' folder, theater register and maternity delivery register. Results: We recorded 5791 deliveries, out of which 89 were placental abruption cases giving a rate of $1.54 \%$ of deliveries. The women most affected were whose with age ranging 25 - 30 years $(30.33 \%)$, the nulliparous women $(32.58 \%)$, the married women $(83.52 \%)$ and whose with bad antenatal clinic attendance (54.6\%). The clinical aspect was most often complete: nil fetal heart rate $(82.00 \%)$, hypertony uterine $(79.90 \%)$ and vaginal bleeding $(74.20 \%)$ were the most signs found. Spontaneous vaginal delivery has been made in $64.04 \%$. Maternal prognosis was dominated by a morbidity linked by an anemia in $53.90 \%$. Maternal lethality was $2.20 \%$. Fetal newborn-death was $88.80 \%$. Conclusion: Placental abruption represents an obstetrical and medical emergency by its start of brutal installation, its unforeseeable character and its materno-fetal consequences. Only a tacking of risk populations, precocious of diagnosis and a speed management in surgical and medical unit allow improving the prognosis of this disease. 


\section{Keywords}

Placental Abruption, Rate, Risk Factors, Prognosis, Maternal, Neonatal

\section{Introduction}

Women health is part of World Health Organization worries (WHO) for long time and becomes the international priority today [1]. In 2005, maternal mortality was estimated of 830 deaths for 100,000 newborns in developing countries against 24 for 100,000 newborns in Europe countries. Haemorrhage was the main maternal death cause (34\%) followed by infections (21\%), risked abortions (18\%) and hypertension states (16\%).

The premature detachment of a normal insertion of placenta or Placental abruption is a serious complication of pregnancy occurring usually at the third trimester and involving the prognosis of mother and fetus. It is an obstetrical emergency.

- In France, the frequency of placental abruption varies between $0.25 \%$ and $0.5 \%$ [2] [3].

- In Anglo-Saxons countries, the rate observed is slightly elevated, between $1 \%$ and $2 \%$ [4] [5].

- In Ivory Coast Republic, in 70 cases studied, Mian et al. found a rate of $1.55 \%$ of placental abruption [6].

- In Burkina Faso: Thieba et al. reported a rate of 0.96\% [7].

With adoption by the government of Burkina Faso of national strategy for obstetric and neonatal emergency care sponsoring, improvements were performed. Placental abruption, one of biggest surgical and medical emergency departments is a concern in obstetrics and gynecology service of regional hospital center of Ouahigouya.

Our study objective was to establish the epidemiological, clinical ant therapeutic aspects of placental abruption in the service of obstetrics and gynecology of regional hospital center of Ouahigouya from 2013 to 2015.

The regional hospital center is the referral hospital of six (6) sanitary districts of north region which are: Ouahigouya, Titao, Séguenega, Gourcy, Thiou and Yako. Its population zone of cover is estimated of 1,306,609 inhabitants.

\section{Patients and Methods}

The study was performed in the Obstetrics and gynecology service of this hospital.

We conducted a cross-sectional study with descriptive type and a retrospective collect of data over two (02) years, from $1^{\text {st }}$ January 32013 to $31^{\text {st }}$ December 2015.

Were included in the study, patients presented clinical signs and or ultrasound of placental abruption with a gestational age greater than 28 weeks of amenorrhea admitted in the obstetrics and gynecology service of regional hospital center of Ouahigouya.

Non inclusion criteria involving patients whom medical folder was unusable (incomplete medical folder).

Variables obtained were about sociodemographics characteristic (age, parity, Residency, occupation, marital status), patients clinical characteristic (mode of admission, gestational age, clinical signs), management and the maternal and neonatal outcomes. 
Using a questionnaire pre-tested, data were collected by the obstetrics folders, theatre register and maternity delivery register. Data collected were analysed using a software Epi-Info version 3.5.4. The results were presented in percentage for qualitative variables and mean and gap-type for quantitative variables.

\section{Results}

\subsection{Frequency of Placental Abruption}

During the study period, we recorded 5791 deliveries out of which, 89 were placental abruption cases. The rate of placental abruption was $1.5 \%$ of deliveries, then 30 cases per year.

\subsection{Sociodemographic Characteristics of Patients}

The mean age was 29.6 years with extreme of 14 and 45 years, $56.2 \%$ of patients were less than 30 years old. The mean parity was $2 \pm 2$. The biggest parity was 11 and the nulliparous women were represented with $32.6 \%$ of cases.

We noted that $43.8 \%$ of patients were from urban district of Ouahigouya, $52.8 \%$ of patients were from the others districts of region of North (Gourcy, Séguenega, Titao, Yako) and 3.4\% were from the districts located beyond of zone of cover of region of North.

In our study, $82(92.1 \%)$ patients had non-salary occupation, the housewives represented $80.9 \%$ (72 patients). The married women were represented in $83.5 \%$ of the sample.

\subsection{Clinical Aspects}

The referred patients represented $88.8 \%$ (79/89). The mean gestational age was 36 weeks of amenorrhea and $92.9 \%$ (78/89) of placental abruption cases occurred in the third trimester of pregnancy. The half of sample had less 3 antenatal clinic visits. The main clinical signs at the admission were: absence of fetal heart rate (82\%), uterine hypertonicity $(79.8 \%)$ and painless vaginal bleeding (74.2\%), 20.2\% had hypertensive disease prior to admission admission.

Table 1 shows the distribution according to clinical signs at admission.

The placenta cupule diameter (measured from one edge to the other with a tape measure at examination of the placenta) was evaluated in 47 cases (52.8\%). That diameter was varying of $2 \mathrm{~cm}$ of whole maternal placental area.

Table 1. Distribution of patients according to clinical signs at admission.

\begin{tabular}{ccc}
\hline Clinical signs & Number & Percentage \\
\hline Painless vaginal bleedings & 66 & 74.2 \\
Uterine hypertonicity & 71 & 79.8 \\
Hypertension & 18 & 20.2 \\
Absence of fetal heart rate & 73 & 82.0 \\
Collapse state & 02 & 2.2 \\
\hline
\end{tabular}


The severity of clinical signs by the use of SHER classification [8] allowed to arrange $84.3 \%$ of cases in the grade $3 ; 10.1 \%$ of cases presented a state of coagulopathy (grade 3B).

Table 2 shows the repartition of patients according the SHER classification.

\subsection{The Therapeutic Management}

The spontaneous vaginal labor was possible in 57 patients (64.0\%). The mean delay of evacuation of uterus was 252 minutes and with extreme of 36 and 1234 minutes.

Blood transfusion with whole blood has been performed in 52 patients, $58.4 \%$ of placental abruption cases and hypertension drugs have been administrated in $15.7 \%$ of cases.

\subsection{Placental Abruption Prognosis}

\subsubsection{Maternal Prognosis}

The mean duration of stay was 3 days with extrems of 1 day and 26 days. Maternal complications were dominated by an acute anemia (53.90\%) abnormal coagulation (10.1\%) and infections (6.7\%).

Table 3 illustrates the repartition according to maternal complications.

We recorded 2 cases of maternal death involving placental abruption, giving a mortality rate of $2.2 \%$. During the study period, 150 maternal deaths were recorded in the service out of which, $1.3 \%$ was from placental abruption. The result of univaried analysis between maternal prognosis and prognosis factors show there is an association significant statically between mode of admission, mode of delivery and gestational hypertension. There was no association between maternal prognosis and parity.

Table 4 shows the distribution of maternal prognosis by risk factors.

Table 2. Repartition of patients according to the SHER classification $(n=89)$.

\begin{tabular}{ccc}
\hline Classification & Number & Percentage \\
\hline Grade 1 & 08 & 9 \\
Grade 2 & 06 & 6.7 \\
Grade 3a & 66 & 74.1 \\
Grade 3b & 09 & 10.1 \\
Total & 89 & 100.0 \\
\hline
\end{tabular}

Table 3. Repartition according to maternal complications.

\begin{tabular}{ccc}
\hline Complications & Number & Percentage \\
\hline Anemia & 48 & 53.9 \\
Coagulopathy & 09 & 10.1 \\
Hypovolemy collapsus & 02 & 2.2 \\
Infection & 06 & 6.7 \\
Kidney deficiency & 04 & 4.5 \\
\hline
\end{tabular}


Table 4. Distribution of maternal prognosis by risk factors.

\begin{tabular}{|c|c|c|c|c|}
\hline \multirow{2}{*}{ Prognosis factors } & \multicolumn{2}{|c|}{ Maternal prognosis $\%(n=89)$} & \multirow{2}{*}{$\mathrm{X}^{2}$} & \multirow{2}{*}{$P$-value } \\
\hline & Good & $\mathrm{Bad}$ & & \\
\hline Mode of admission & & & & 0.027 \\
\hline Direct & 93.8 & 6.2 & & \\
\hline Refered & 84.5 & 15.5 & & \\
\hline Mode of delivery & & & 5.086 & 0.005 \\
\hline Vaginal & 92 & 8 & & \\
\hline C-section & 83.5 & 16.5 & & \\
\hline Gestational hypertension & & & & 0.039 \\
\hline Yes & 70.3 & 29.7 & & \\
\hline No & 86.8 & 13.2 & & \\
\hline Parity & & & 0.047 & 0.422 \\
\hline $0-3$ & 87.3 & 12.7 & & \\
\hline 4 and more & 86.5 & 13.5 & & \\
\hline
\end{tabular}

\subsubsection{Neonatal Prognosis}

We recorded during the study, 79 neonatal deaths giving a rate of neonatalde of $88.8 \%$ (Including 6 pending delivery, or 6.7\%). The results of unvaried analysis between fetal prognosis and prognosis factors show an association statically significant between number of antenatal clinic visits performed, mode of admission, mode of delivery. There was no association between fetal prognosis and gestational hypertension.

Table 5 illustrates the repartition of newborns by prognosis factors.

\section{Discussion}

\subsection{Limitations of Study}

Due to retrospective collect of data, we notice the following limitations: the miss data for some of variables. As well, our cases were selected in the folders based on which the placenta examination was mentioned. It is obvious some placental abruption cases were miss, then an under-estimation of frequency of this disease.

\subsection{Frequency of Placental Abruption}

In our study, the frequency of placental abruption was $1.5 \%$. That is similar to those reported by Mian et al. and Doumbia in Ivory Coast [6] [9] who found respectively $1.55 \%$ and $1.46 \%$. It is higher than that of Thiéba in Burkina Faso and Touré in Ivory Coast [7] [10] who reported 0.96 and $0.90 \%$ respectively. On the other hand, our frequency is twice or 3 times lower than those reported in Nigerien [10] and Senegalese [11] studies, respectively $3.6 \%$ and $6.05 \%$.

These African rates remain higher to those from European studies which vary from 0.20 to $2 \%$ [2] [3] [12].

Lots of studies around the world have shown that the advanced age of women was a risk factor of placental abruption [7] [13] [14]. So, it is a third decade accident. 
Table 5. Repartition of newborns by prognosis factors.

\begin{tabular}{ccccc}
\hline \multirow{2}{*}{ Prognosis factors } & \multicolumn{2}{c}{ Fetal prognosis $\%$} & \multirow{2}{*}{$\mathrm{X}^{2}$} & $P$-value \\
\cline { 2 - 3 } & Good & Bad & & 0.002 \\
\hline Number of ANC & $(\mathrm{n}=86)$ & 83.7 & & \\
$0-2$ & 16.3 & 69.9 & & 0.008 \\
$3-5$ and more & 30.1 & & \\
Mode of admission & $(\mathrm{n}=89)$ & 63.1 & \\
Direct & 36.9 & 78.2 & \\
Refered & 21.8 & & \\
Mode of delivery & $(\mathrm{n}=89)$ & & \\
Vaginal & 8.1 & 91.9 & \\
C-section & 30.0 & 70.0 & & \\
Gestational hypertension & $(\mathrm{n}=89)$ & & \\
Yes & 32.7 & 67.3 & \\
No & 23.9 & 76.1 & \\
\hline
\end{tabular}

However, in our study, the mean age of patients was $29.58 \% \pm 6.12 \%$ years and the range of 25 - 30 was most affected (30.33\%). Our results seem to be closed to literature where the mean ages varied between 28.5 and 31.3 years [9] [14] [15].

The young age of our patients may be linked to socio-cultural factors especially the precocity of marriage.

\subsection{Clinical Aspects of Placental Abruption}

The bad antenatal clinic attendance is a factor leading to placental abruption. In our study, $54.60 \%$ had less than 3 antenatal clinic visits. This rate is comparable to those found by Thiéba in Burkina Faso (61.20\%) and Sarr in Senegal (47.90\%) [7] [16].

Akpadza in Togo [17] realized that the rate of placental abruption trend to decrease when the number of antenatal clinic performed increases.

The lack of adequate follow up of pregnancy with for corollary under-estimation and a late track down of risk factors lead to a low rate of reference during pregnancy and an important rate of emergency referral (88.80\%).

In our study, the main clinical signs found at admission were: No fetal heart rate (82\%), uterine hypertonicity (79.8\%), painless vaginal bleeding (74.2\%) and hypertension $(20.2 \%)$. Indeed, the fetal heart rate was present in $18 \%$ of cases. A similar rate of 17\% has found by Thiéba in Burkina Faso [7]. Others authors such as Diouf in Senegal, Doumbia in Ivory Coast have found rates of $23.30 \%$ and $22.30 \%$ [18] [19]. On the other hand in Europe, $30 \%$ to $50 \%$ of placental abruption is complicated by intrauterine fetal death [9]. We should base on the quality of antenatal clinic attendance during pregnancy that can help to refer on time the patients with an obvious risk to another high level hospital and avoid an emergency referral which may reduce the fetal prognosis.

\subsection{Therapeutic Management}

The precocious and a speed evacuation of uterus is the base of obstetrical treatment of 
placental abruption. Spontaneous vaginal delivery was the main mode of delivery in our study with a rate of $64 \%$, the rate of cesarean section was $35 \%$. Similar studies are reported by Thiéba in Burkina Faso and Akapadza in Togo [7] [17]. On the other hand, a lower cesarean rate has reported by Doumbia in Ivory Coast and Nayama in Niger, respectively $63.2 \%$ and $94.10 \%$ [9] [12]. However, is it suitable to notice that vaginal delivery with intrauterine fetal death was common in maternity of regional hospital center; the cesarean section was indicated when the fetus is alive or the occurring of complications such as coagulopathy or whatever obstetrical complications. For this latter situation, the cesarean is indicated for maternal lifesaving.

\subsection{Prognosis of Placental Abruption}

In our study, as in most of studies [7] [9] [17], maternal morbidity is dominated by acute anemia; due to hemorrhage which is the direct consequence of abnormal coagulation combine with uterine atony [20]. Abnormal coagulation was observed in $11.60 \%$ but lower than that found by Thieba in Burkina Faso [7] (4.50\%. That low rate may link to unavailable of laboratory exam in our work area.

Lethality was $2.2 \%$ in our study. That is comparable to reported by Doumbia in Ivory Coast [9] who found 2.90\%. However, our result remain lower than others African studies where was varying $3.90 \%$ and $5.10 \%$ [7] [12] [14]. These deaths were linked to later diagnosis and difficulties for treatment especially insufficiency of means for resuscitation face to huge and prolonged bleeding (lack of blood and derivative for transfusion).

The fetal prognosis is dark view the rate of fetal mortality of $88.76 \%$ in our study. That is comparable to those found by others African authors [7] [9] [14] [18]. It reveals the late of diagnosis and the management before admission of patients.

\section{Conclusion}

Placental abruption is an obstetrical disease still common in developing countries. It is associated with a heavy maternal and fetal morbi-mortality. The diagnosis and the treatment should be performed without any late; it will help to improve the maternal and fetal prognosis. In African context, that goes by an improvement of care quality, equipment of reference sanitary building with resuscitation instruments and the availability of blood products.

\section{Acknowledgements}

Our sincere thanks to the management team of the Ouahigouya Center Hospital University who granted us permission to conduct the study. We also thank the University Ouaga I Pr Joseph KY ZERBO, Medicine Section for all the support.

\section{References}

[1] WHO (2009) Women and Health: The Reality of Today's Program of Tomorrow. Information Report, 94 p.

[2] Bohec, C., et al. (2015) Placental Abruption; Formal Recommendations of Experts. French Annals of Anesthesia and Reanimation, 29, 115-119.

https://doi.org/10.1016/j.annfar.2010.03.011 
[3] Saulières, H. (2002) Placental Abruption. Pyrenean Days Gynecology and Obstetrics Tarbes, 4-5.

[4] Oyelese, Y. and Ananth, C.V. (2006) Placental Abruption. Obstetrics \& Gynecology, 108, 1005-1016. https://doi.org/10.1097/01.AOG.0000239439.04364.9a

[5] Tikkanen, M., Luukkaala, T., Gissler, M., Ritvanen, A., Ylikorkala, O. and Paavonen, J. (2012) Decreasing Perinatal Mortality in Placental Abruption. Acta Obstetricia et Gynecologica Scandinavica, 92, 298-305. https://doi.org/10.1111/aogs.12030

[6] Mian, D.B., Angoi, V., N'guessan, K.L.P., Abauleth, Y.R., Kouakou, F. and Boni, S. (2014) Placental Abruption and Fetal Death in Utero about 70 Cases at Cocody University Hospital and Review of the Literature. RAMUR, Tome 19.

[7] Thiéba, B., Lankoandé, J., Akotionga, M., Koné, B., Ouédraogo, A. and Kyelem, C. (2003) The Placental Abruption in the Gynecology and Obstetrics Department of the National Hospital Center Yalgado Ouédraogo of Ouagadougou: Epidemiological, Clinical and Prognostic Aspects. Gynécologie Obstétrique \& Fertilité, 31, 429-433.

[8] Sher, G. (1978) A Rational Basis for the Management of Abruptio Placentae. Journal of Reproductive Medicine, 21, 123-129.

[9] Doumbia, Y., Kouakou, K.P., Djanhan, L.E., Menin, M.M., Kone, D.D.A. and Djanhan, Y. (2013) The Placental Abruptionat the Bouaké University Hospital: About 524 Cases. Journal of SAGO, 14, 39-44.

[10] Touré-Coulibaly, K., Aïssa, G., Jano, N., Kouyate, S., Guié, P. and Doumbia, Y. (1995) The Premature Detachment of the Normally Inserted Placenta, Fetal-Maternal Prognosis. About 102 Cases Collected at the Obstetric Clinic of the UHC of Treichville. Black Med. Afr., 42, 540-547.

[11] Bâ, M.G., Faye, E.O., Kpekpéde, F., Drave, A., Manikassé, P., Fotso, A., et al. (2005) Maternal Morbidity and Therapeutic Modalities in the Management of Placental Abruption at the CHU Dakar. Mali Médical, 20, 1-3.

[12] Merger, R., Levy, J. and Melchior, J. (2001) Abruptio Placentae. Precis of Obstetrics. 6th Edition, MASSON, Paris, 635.

[13] Nayama, M., Tamakloé-Azamesu, D., Garba, M., Idi, N., Djibril, B., Kamaye, M., Marafa, A., Touré, A., Diallo, F.Z. and Houfflin-Debarge, V. (2007) Abruptio Placentae. Management in a Reference Nigerien Maternity. Prospective Study about 118 Cases during One Year. Gynecology and Obstetrics and Fertility, 35, 975-981. https://doi.org/10.1016/j.gyobfe.2007.05.023

[14] Thiam, O., Mbaye, M., Diouf, A.A., Touré, F.B., Gaye, M., Niang, M., Cissé, L.M., Dièye, S. and Moreau, J.C. (2014) Prognostic and Therapeutic Epidemiological Aspects of Placental Abruption in a Maternityreferral in Rural Area (RHC de Ndioum). The Pan African Medical Journal, 17, 11.

[15] Boisramé, T., Sananès, N., Fritz, G., Boudier, E., Viville, B., Aïssi, G., et al. (2014) Abruptio Placentae. Diagnosis, Management and Maternal-Fetal Prognosis: A Retrospective Study of 100 Cases. Gynécologie Obstétrique \& Fertilité, 42, 78-83. https://doi.org/10.1016/j.gyobfe.2013.06.012

[16] Sarr, F.R., Diouf, A., Cissé, M.L., Faye, E.O. and Moreau, J.C. (2003) Management and Prognosis of Placental Abruption in a University Hospital Center in Dakar, Senegal. Journal of SAGO, 5, 6-11.

[17] Akpadza, A.K., Baeta, S., Neglo, Y., Tete, U. and Hodonou, A.K. (1996) Placental Abruption at the Gynecological Clinic of the Tokoin University Hospital in Lomé (Togo) from 1988 to 1992. Black Med. Afr., 43, 342-347.

[18] Diouf, A., Thiam, A., Gaye, A. and Moreau, J.C. (2004) Management and Prognosis of Placental Abruption in a District Maternity Clinic in Dakar, Senegal. Journal of the SAGO, 5, 
29-35.

[19] UZan, M., Haddad, B. and Uzan, S. (1995) Placental Abruption. Encycl Méd Chir (Elsevier, Paris), Obstétrique 5071-A-10, 8p.

[20] Igwegbe, A.O., Eleje, G.U. and Okpala, B.C. (2013) Management Outcomes of Abruptio Placentae at Nnamdi Azikiwe University Teaching Hospital, Nnewi, Nigeria. Nigerian Journal of Medicine, 22, 234-238.

Submit or recommend next manuscript to SCIRP and we will provide best service for you:

Accepting pre-submission inquiries through Email, Facebook, LinkedIn, Twitter, etc. A wide selection of journals (inclusive of 9 subjects, more than 200 journals)

Providing 24-hour high-quality service User-friendly online submission system Fair and swift peer-review system Efficient typesetting and proofreading procedure Display of the result of downloads and visits, as well as the number of cited articles Maximum dissemination of your research work

Submit your manuscript at: http://papersubmission.scirp.org/

Or contact ojog@scirp.org 